\title{
Organization Design in Football Management Process
}

\author{
Serdar Samur \\ Assistant Prof. Dr., Head of Sports Management, Physical Education and Sports School, Gelişim University, Avcılar, İstanbul, Turkey
}

Copyright $\mathrm{C} 2018$ by authors, all rights reserved. Authors agree that this article remains permanently open access under the terms of the Creative Commons Attribution License 4.0 International License

\begin{abstract}
Nowadays, to create efficiency, businesses need to build expert departments (systematic structure) based on functional business section, accelerate the flow of information in itself and enable decisions to be taken more quickly, thus saving time and resources and taking measures against risks by constantly monitoring hierarchical structures. In the Sports Clubs, it is important to transfer the financial power, which is the result of sportive achievement, to the whole activity areas in the club in a balanced manner and to substructure investments to develop and grow and create economic magnitude and transform this magnitude to contribute to sportive achievement again. The purpose of this study is to split the football management into main processes and manage easily. In a system approach to manage football management areas with different variables in accordance with organizational goals in a harmony, sports clubs should separate ' 8 ' main process like Team Intelligence, Team Management, Youth Development, Footballer Transfer, Logistics Support, Public Relations and Corporate Communication, Economy-Finance, Sports Law. By means of these processes, Clubs can implement performance management and development, apply organizational learning and knowledge management and target continuous improvement and development.
\end{abstract}

Keywords Process Management, System Approach, Performance, Success, Economy

\section{Introduction}

According to UEFA [1], [cited 2018 April 5] available from http://www.uefa.com., the top management unit of football, requires professional teams to continually improve the management standard, achieve organizational levels that will increase economic and financial opportunities, bring more discipline and rationality to football accounting, and achieve effective management and organizational skills through income generated by football These demands from UEFA brings a systematic approach to organize existing sports facilities in the framework of today's business principles with organizational structure of football, management styles, sportive, financial, legal and sportive substructure, in other words institutional management to the agenda.

Today's businesses include applications such as Total Quality Management, Core Capability, Benefits from Outsourcing, Change Engineering, Benchmarking, Downsizing and Stage Reduction, Matrix Organization Structure and Project Management.

In our age, Atak [2] asserts that businesses are accepted as living organisms. Businesses that are aware of this change today have begun to prefer to transition from a result-oriented work system to process management, closely following customer expectations in order to exist in the future as well.

Continuous control and improvement of the process and long-lasting and stable determination of the error-free results are necessary. Çetin, Akın and Erol [3] emphasize that if management does not establish systems to improve processes, it will fail in the end results.

The process is a sequence of related activities and operations that start with an input and produce a needed output by adding value.

Some organizational principles that still maintain their validity in the Management Process Approaches, which is one of the classical management approaches in organizational design, are basically used as follows: According to Robbins, Stephen and Judge [4] argue that Division of labor and Specialization, Division of departments, Order Command Structure, Hierarchical Structure, Control Field, Balance of Authority and Responsibility, Centralization, Number of Stages.

A direction of these principles towards the objectives determined within a certain order is possible with the system approach.

Doğan [5] highlights the system is conceptually defined as an organized and indivisible, consisting of two or more parts or sub-systems that are dependent on each other, with a certain limit in terms of their operating characteristics, distinguished from other systems, or related to the external environment from subsystems.

The information needs also differ in different branches of the organization due to their different activities, working styles and differences in their structures, and as a result the 
information systems of different qualities in organizations are classified according to organizational structure or administrative level, functions, operations or activities, decision support, architectural structure, support areas.

Management of businesses with functional (vertical) structures causes communication problems between departments and unnecessary competition. In process management, organizations are directed towards a horizontal structure that is easier to communicate in system approach. Ewalt [6] found that the steps of process management are:

- Determination of processes,

- Identification of the processes and presentation of the current situation,

- Identification of process owners and formation of teams,

- Identification of relationships between processes,

- Determination of key processes,

- Determination of process performance indicators.

Today, many sports clubs are incorporated. The main goal of sports clubs is to increase their profits in addition to achieving success in their sports branch. Hence, clubs are choosing ways to increase their profits by reflecting their competition in the sporting field to commercial areas. Yavaş [7] highlights that Sports clubs need to increase their profits and make good decisions by analyzing the current economic situation survive.

The clubs we are used to seeing every season in European cups tries to sustain a structure with a correct upper system that runs and manages the system in a competitive environment where winning the European Cup is not at all easy, and the quality of the teams in terms of economy and quality is very high [8],[9].

As emphasized by Samur [10] that the clubs have started to be professional in their field of activity with the aim of giving an opportunity to professional teams, which are the main element of sporty success, to reach top performance. In this context:

- $\quad$ Both team players and competitors are analyzed with computerized analysis programs with a good target team analysis by the technical staff

- Scout teams are created to supply new players at the right time in the team to improve team harmony,

- $\quad$ Sports facilities are being modernized in order to increase team success and to gain more support from fans,

- Public relations and corporate communication methods are being developed to form a strong communication channel with the club.

In addition, Stoner [11] emphasizes sports clubs are also striving to establish a management information system that enables them to effectively manage the functions of planning and acting within the organization and to enable managers to use the timely information to facilitate the decision-making process. Plunkett and Attner [12] advocates that The management information system which provide information flow by linking different factors and consists of organizational elements such as information on accounting, sales, requests and warehouse stocks, reports, processes, audits are becoming a series of systems in which information is structured to help decision making.

The aim of this study is to determine the main process elements of the area of football that produces service with different dynamics and to make this area suitable for process management in order to provide sportive success in football clubs and to ensure continuity in accordance with the changes in today's organizational structures.

\section{Method}

\section{Research Model}

Research has been conducted in a qualitative way. Yıldırım and Şimşek [13] found that Qualitative research uses qualitative data collection methods such as observation, interview and document analysis, and attempts to put the perceptions and events in a natural and realistic way.

\section{Study Group}

The population of this research consists of European teams that we see in the top 10 in every season and 3 Turkish clubs.

\section{Development of Data Collection Tool}

Data were collected from the websites of the clubs that we see in the top 10 in UEFA leagues and from Turkish clubs via interview method.

Intermediate level managers were selected for the meetings with the clubs and interviews were held with semi-structured questions. Each of the questions was prepared to obtain different data. As the interview technique, Patton's "approach of interview form" was used. Four open-ended and semi-structured questions were pre-prepared. The questions asked to the Sports Managers in the interview form are as follows:

- Which subjects are considered as the main field in football management, why?

- Which subjects are important to succeed in Football?

- Why is raising a sportsman important?

- Why is public relations and corporate communication important for the club?

\section{Data Analysis}

Data were first written by the researchers in computer environment and then analyzed using content analysis which is one of the qualitative research techniques. The answers given by the department managers to each question were interpreted by grouping in terms of similarities. In order to increase the reliability of the study, analyzes of a specialist were taken into consideration and common points were determined. 


\section{Findings}

\subsection{Contemporary Approaches in Football Management}

When we examine the common points of the sports clubs that we have frequently encountered in European cups, the structure where the system is preferred rather than the people, which is a new identity that implements contemporary and scientific norms very well and heads straight for the top and become popular in Europe stands out Within this structure [14,15] [cited 2018 April 5] available from http://www.fcbarcelona.com reflects that it is important to maintain an organizational structure in which have a professional squad based on the ability to sell players and replace those with good transfers. The policies and strategies that contemporary sports clubs apply to football management and the covered areas are presented in the following table, management matters $[16,17,18,19]$ [cited 2018 April 15] available form http:// www.london.edu., www.cmoe.com, www.telegraph.co.uk www.hbr.org

Policies and Strategies Used in Contemporary Sports Clubs

\begin{tabular}{|c|c|c|}
\hline S. No & Policy/Strategy & Covered Area \\
\hline 1 & $\begin{array}{l}\text { Forming a structure built on a continuous restructuring system rather than being a } \\
\text { project team }\end{array}$ & Corporate Governance \\
\hline 2 & $\begin{array}{l}\text { Being the favorite club of the transfer market by chasing the UEFA championships in } \\
\text { the team profile of player selling, }\end{array}$ & Transfer \\
\hline 3 & $\begin{array}{l}\text { Creating a club culture, not giving up the established values, } \\
\text { Resolving the conflicts that arise between the subjects of the sport, respecting the sports } \\
\text { law and ethics, }\end{array}$ & Corporate Governance-Sports Law \\
\hline 4 & $\begin{array}{l}\text { Providing stability through the protection of the system rather than performance in the } \\
\text { field, }\end{array}$ & $\begin{array}{c}\text { Training and } \\
\text { Performance management }\end{array}$ \\
\hline 5 & $\begin{array}{l}\text { Making effort to match manager-squad correctly, } \\
\text { Providing continuity in performance management }\end{array}$ & $\begin{array}{c}\text { Training and } \\
\text { Performance management }\end{array}$ \\
\hline 7 & Being a team that is questioning and conscious, & $\begin{array}{c}\text { Training and } \\
\text { Performance management }\end{array}$ \\
\hline 8 & Target Team Analysis and Performance Monitoring & $\begin{array}{l}\text { Target Team } \\
\text { Intelligence }\end{array}$ \\
\hline 9 & Having players with fidelity, & $\begin{array}{l}\text { Youth Development } \\
\text { Program }\end{array}$ \\
\hline 10 & $\begin{array}{l}\text { Keeping a full hit on the transfer, not having bad transfers, keeping in mind the fact that } \\
\text { the performance of a player depends on many parameters }\end{array}$ & Scout and Transfer \\
\hline 11 & Creating a challenging and productive substructure, & Youth Development Program \\
\hline 12 & $\begin{array}{l}\text { Creating a football management culture that gives opportunity to young players who } \\
\text { grown up in the youth setup, }\end{array}$ & $\begin{array}{c}\text { Training and } \\
\text { Performance management }\end{array}$ \\
\hline 13 & Making the potential star transfers that no one else has heard yet, & Transfer, \\
\hline 14 & Creating loyal fans, & Public relations and Communication \\
\hline 15 & $\begin{array}{l}\text { Forming strong sponsorships, Ensuring budget balance within the budget discipline for } \\
\text { efficient use of economic resources, Managing cash flow efficiently, }\end{array}$ & $\begin{array}{c}\text { Finance and } \\
\text { Economics }\end{array}$ \\
\hline 16 & Branding and institutionalization, & Corporate Communication \\
\hline 17 & $\begin{array}{l}\text { Being ready for league matches and producing continuous sportive success, Making the } \\
\text { sportive success permanent, }\end{array}$ & Team Management, \\
\hline 18 & $\begin{array}{l}\text { Creating voluntary scouts that are increasing day by day with the football player } \\
\text { monitoring and evaluation center, }\end{array}$ & Scout and Transfer \\
\hline 19 & $\begin{array}{l}\text { Following the technological innovations with the production of goods and services and } \\
\text { providing facility management, }\end{array}$ & Logistics Support \\
\hline
\end{tabular}




\subsection{Topics covered in Football}

Team management and Economics: All participants emphasized that for every professional club, building the skeleton of the good team squad and making investments to ensure its continuity is the most vital subject. Donellon [20] states that a team is a group of people who are obliged to come together to carry out a task that requires the continuous unification of the expertise skills that are dispersed among themselves.

If you do not create the team composition well, if the chemistry of the team does not match, if you do not pay attention to the differences and balance in the individual thinking structures and in the role distribution within the team, you will not have synergistic teamwork. Synergy brings team intelligence. Team intelligence is superior and has broader perspective than individual mind. At the point where the team spirit does not form, the total power will be less than the individual power. Toktamışoğlu [21] says that If you pick the pieces well and those piece complete each other, the whole will be bigger than the sum of the pieces

Participants stated that the establishment of a good team will bring sportive success and the sportive success will lead to the evaluation of the brand and the increase in the number of supporters and thus the number of the people following the matches will increase, the players will become more popular in the transfer market and club can get more economic resources from the football market. It is suggested that this obtained economic resources should be used for the transfer of players who has potential, technological investment and sportive substructure. The most important budget item in Sports club is the transfer budget and the most important criterion in transfer is the importance of establishing a system in order to ensure the supply of players to the professional team with the correct time, correct features and the appropriate price.

Target Team Analysis and Evaluation Unit: Nowadays, analyzes made to evaluate team or player performances reveal a more meaningful "Image Based Statistical Analysis" method by using images and statistics together [22], [cited 2018 April 15] available form http://tr.matchstudy.com.

Participants stated that analysis in a football club is being done by compiling events in the field through computer programs, and the resulting information is interpreted and evaluated in order to transform the information needed by the coaches.

However, it is emphasized that the analysis process is not possible with club facilities, because the transformation of the facts generated during the match to the statistical data by the data processor, the transformation of to the information by the assistant coaches and by the head coaches take too much time.

This need for target team of high-level clubs in Europe was determined through online sources provided by Sports Universities and the organizations that are experts in this area, rather than clubs.
Player Training, Substructure: Among the license criteria of UEFA [23], [cited 2018 April 10 available form $\mathrm{http}: / /$ uefa.com. which is the highest level of football, there are substructure criteria about training players and sportive criteria.

Sportive Criteria: These are criteria of clubs to develop a mutual understanding between those concerned (players, referees, technical trainers and attendants), to make the youth to strive for their sportive and academic education and to employ competent technical trainers for this purpose, and to adopt fair play in and outside of the field.

Substructure criteria: These are criteria to establish facilities of equal quality in terms of equipment and cleanliness, to build new stadiums that enable spectators to feel safe and comfortable and enable members of the press to fulfill their duties properly and to build training facilities to provide an opportunity to players to improve themselves.

Participants expressed that it is possible to advertise the club with school visits in order to reach qualified sportsmen and gain fans, but it is more important to work on the construction of football academies for the training of players.

It was stated that youth camps and special competition organizations are organized (league of teeny, league of stars, leagues of youth A and B, school matches, national team selections, etc.) to identify the footballers who may be potential stars in particular.

Participants stated that the players who were raised with the Youth Development Programs should be used effectively in the primary team, there should be stability in terms of coach and player changes, and thus reachable short-medium-long term planning towards goals should be made.

Fan-Public Relations and Corporate Communication: Prindle [24] considers that public relations generally relate to communication activities aimed at protecting an institution's relations with the public. Aleshina [25] asserts that Public Relations activities can be directed towards various social groups (broad or local community) or to specific targets (institutional image formation or overcoming crisis).

At the present time Peltekoğlu [26] put forth that public relations, the interpretation of the management art based on the mutual-based approach which leads the attitudes by evaluating the reactions, establishing and developing solid bonds with private and legal people, leading them to positive beliefs and actions are also important.

Participants expressed that fans who are the most important active asset of industrial football are being evolved towards a customer and the average audience profile is now being replaced to spectators that have a higher level of income spending as a fan-consumer on the basis of loyalty to the club. In order to increase the dependence of fans on the clubs, it was stated that many methods such as establishing healthy communication, creating a sense of belonging and being open to innovative 
ideas are tried to be used together effectively.

A club is thought to have a higher number of followers, and thus higher income, if the fans' wishes and expectations are identified and appropriate quality of service is provided early. Participants stated that although the fans of sports clubs are their primary audience, there are also a large number of spectators called football lovers who follow football, consume it through the media.

It appears that the social media (Website, Facebook-Instagram-YouTube and Twitter) accounts are actively used for promotional activities of the clubs according to both opinions of participants and applications of sports clubs.

Economics-Finance: The advantage of having a strong brand is possible with the license of the product of the organization. A license is an agreement made by a company or an organization to give its brand for a specific agreement or payment. As a broader definition, Berkowitz and Hartley [27] allege that license is a form of agreement, in which an organization grants the authority to another organization to use its trademark name for a fee or a concession.

Participants expressed that the Club tries to make long-term sponsorship agreements with fixed income sources, register spectators/supporters for membership fees and give importance to merchandising for a strong economic structure that will create its own financial strength.

The marketing of the football players' jerseys which are the appeal of the fans/customers, and going to events with these jerseys have started a new process. The clubs that are aware of this development are also constantly changing their jerseys and using new ways/transfers to make customers buy these products. Talimciler [28] claims that new transfers are now taking place at the official sales outlets of the clubs, and the 'new' jerseys with their names are being signed as promotion.

In this context, it was stated that the fan stores, which is one of the most important resources for the club, has an important role in becoming a life brand and that the club is trying to establish a strong connection by combining the sense of belonging, logo and colors.

The development of merchandising, which is a very important income source for the club, is being promoted and these are being spread rapidly with franchising model.

Corporate Governance and Law: Participants stated that the management of the club is divided into two main areas, administratively and technically, and that they are trying to reveal the differences of duty of these areas and to provide power balance between them.

In the face of the increasing commercial importance of clubs, UEFA has criteria to employ qualified and well-trained professionals with certain knowledge, to benefit from competent services in terms of safety, to train all teams by qualified technical instructors and to receive medical support and to ensure that legal structures and operations of clubs are at required level in terms of national and football legislation.

Participants expressed that they prefer to work with competent and technically well-trained managers and sports professionals who are experts in the fields of finance, law, administration, communication and business development and who can capture the dynamics of industrial transformation in football with the supervisory and executive boards of professionals in club management.

The policies applied by the contemporary western sports clubs and the common view of the participants show that the transfer of authority to lower level professionals in the club, the continuity of the technical and team staff, and the account inquiry mechanism are required.

Logistic Support: Services bought and sold between organizations and/or institutional customers constitute the market for industrial services. Johansson and Olhager [29] affirms that the target market for industrial services is the customers who are purchasing services from outside the organizations to support or develop their purchasing, production, sales and other related processes.

Marrian [30] discusses that the services purchased to perform or support the production of goods and services are defined as industrial services. Logistics, together with it's all other activities and concepts, is under this category.

Onal [31] asserts that raising the income level of sports businesses is a way of raising the level of efficiency for people who want to play sports. It is primarily the responsibility of the managers to increase efficiency in the business.

The success of efficiency-enhancing activities depends on the chosen strategy and Ramazanoğlu [32] says that policy, the attitudes of the managers, and applications.

Efil [33] argues that the sports facilities are fields and areas which are equipped with units that will meet the needs of athletes and spectators before and during sports activities (field, tribune, shower, dressing room, etc.) suitable for each sport branch's preparation training, national and international competitions.

Participants expressed that logistically organized units are working on the following subjects in order to supply the goods and services required by the players and administrators at the desired standard, time and place.

Nutrition: Players with intensive training and match programs are trying to keep their meals very carefully both by themselves and the dietitian in the club so that they can use their personal skills in the best way and make it sustainable.

Camping Services: In order to prepare the players for the league in pre-season and half-time period, the camping sites are selected by considering the climate and weather conditions and those training facilities should be in accordance with club's own standards.

Transportation: During the league, the means of transport suitable for the away games is selected and the physical comfort of the football player is kept on the front.

Clothing: Every pre-season, players are provided with 
easy-to-use and comfortable clothing materials they will need during the league.

Training Material: All kinds of technical equipment that will enable the training performance to be improved are kept ready in the training and the technological innovations are closely followed.

Match Analysis Programs: Current computerized match analysis programs are provided so that the coaches can follow the performance of the players and team.

Sports Facilities Management: Sports Facilities should be prepared to meet the needs of players and spectators before and during sports activities (field, tribune, shower, dressing room, etc.), and be suitable for each sports branch's preparation training, national and international competitions.

\section{Discussion and Conclusions}

Nowadays, to create efficiency, Samur [34] argues that businesses need to build expert departments (systematic structure) based on functional business section, accelerate the flow of information in itself and enable decisions to be taken more quickly, thus saving time and resources and taking measures against risks by constantly monitoring hierarchical structures.

In today's market environments where competition is intense, survival of organizations and sustainability of competitive advantage in both national and international markets are dependent on their capabilities to collect and interpret information in a wide range and to act quickly.

Rapidly increasing technological changes and increasing diversity in products and services bring up process management, one of the new management practices. Doğan [35] asserts that process management is the combination of events that transform inputs into business outputs. Sports organizations also have business processes that produce both products and services. These processes require a regular and systematic flow of activities to perform outputs that include inputs such as capital, labor, equipment, raw materials, etc.

In the Sports Clubs, it is important to transfer the financial power, which is the result of sportive achievement, to the whole activity areas in the club in a balanced manner and to substructure investments to develop and grow and create economic magnitude and transform this magnitude to contribute to sportive achievement again. Sports clubs need a model that:

- implements performance management and development,

- targets continuous improvement and development,

- applies organizational learning and knowledge management by taking advantage of management information systems in a system approach to manage football management areas with different variables in accordance with organizational goals in a harmony.
Formation of organizational structure is also a process. Koçal [36] professes that this process involves grouping activities in a meaningful and effective way, making these groups into specific organizational levels and positions, and assigning employees to these positions.

The creation of value as a part of a top system of football management within the framework of organizational structures of contemporary sports clubs is an ideal structuring. The conceptual areas of this structuring also give us important clues about departments. These are:

Team Management and Economics: For sports clubs, creating a team that will produce sportive success and ensuring continuity of this success is the top priority. Efforts are being made to establish a unit that will guide the player transfer process correctly and to provide a system that will allow this unit to work with objective data, since the most important budget item in the sports clubs is the transfer budget and this budget should be used in the most appropriate manner to the club values.

In Club Management, it is understood that the latest trend is forming a structure built on a continuous restructuring system rather than being a project team to chase the UEFA championships and to be a favorite club of the transfer market as player-selling team profile

Target Team Analysis and Evaluation Unit: The importance of the target team analysis is increasing with the efforts to improve performance in football It is clear that the accuracy rate will increase in decisions made with objective data.

Sportsmen who are expert in statistics with analytical thinking methods and mathematical reasoning, trained in the technical, tactical and conditional knowledge of football seem to be needed in order to transform the raw data collected from the field by the data processor into information that the coach needs.

The need for such a unit to be set up independently is being addressed by the fact that high-level clubs in Europe take this service from more specialized institutions.

Sports Substructure: The substructure of sports clubs (player training units) are structured qualitatively in the manner required by contemporary football.

Contemporary Football Clubs, with a strong social identity, are transformed into a form that trains elite athletes with scientific methods in the most sports branches in which they operate and markets these athletes effectively.

In terms of football dynamics, the creation of a competitive and productive substructure (facility, training and organization) is becoming one of the main process elements for youth development activities.

Corporate Communication in terms of Fan-Public Relations: it has become important to establish healthy communication in order to increase the dependence of the fans to the clubs. Increasing the quality of service in accordance with the wishes and expectations of the supporters will be an economic activity in return. For this 
purpose, the service responsibility of the sports clubs is increasing with the accelerator effect of the social media in the frame of brand awareness.

In the process of achieving the institution's goals and objectives, corporate communication, which makes a significant contribution to the formation of brand value, should be managed by a unit that will provide coordination, the flow of information, motivation, integration, evaluation, decision-making and coordination between departments or elements of the institution.

Economics-Finance: The ability of a club to engage in actions that create its own financial strength requires a professional perspective.

Continuity in resource flow and a strong economy are becoming the most important factors in achieving sportive goals. In order to ensure the sustainability of this structure, it should be managed by a unit that can provide budgetary alignment within the budget discipline and have strong institutional features in directing the cash flow efficiently.

Corporate governance and law: Recognition of rights of all stakeholders- the general board members, supporters, players, club employees and suppliers- will be an important contributor to establishment of sporting facilities, youth sports opportunities, player training, economic contribution to the region and so on.

Logistic Support: It is noteworthy that in order to carry out logistical activities in the club in a certain order, a structure should be formed under the name of Logistics unit.

It can be seen that the process elements of the subject areas covering football and complementing each other can be categorized as follows.

- Competitor Team Intelligence,

- Team Management (Training and Performance Management and Match Management)

- Youth Development,

- $\quad$ Scouting and Player Transfer

- Logistics Support

- Economics-Finance

- Public Relations and Communication,

\section{- $\quad$ Sports Law}

These main process elements must be seen as an application of a structure like a living organism that gathers the basic components of football. The functional areas shown in Figure-1 will create an environment suitable for realizing the desired purpose by being managed in communication with each other in a horizontal axis.

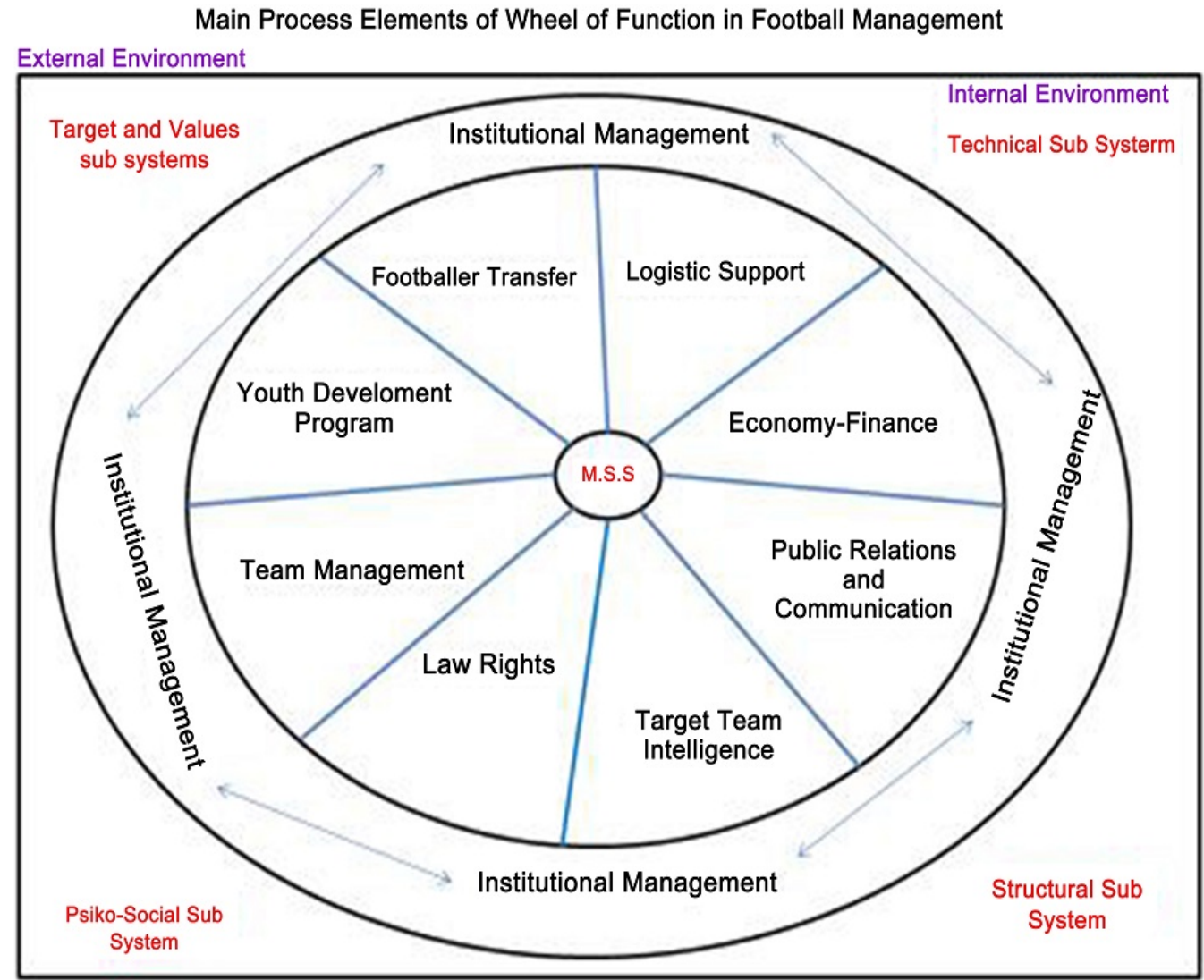

Figure 1. Function Wheel Main Process Elements: (M.S.S: Management Sub System) 


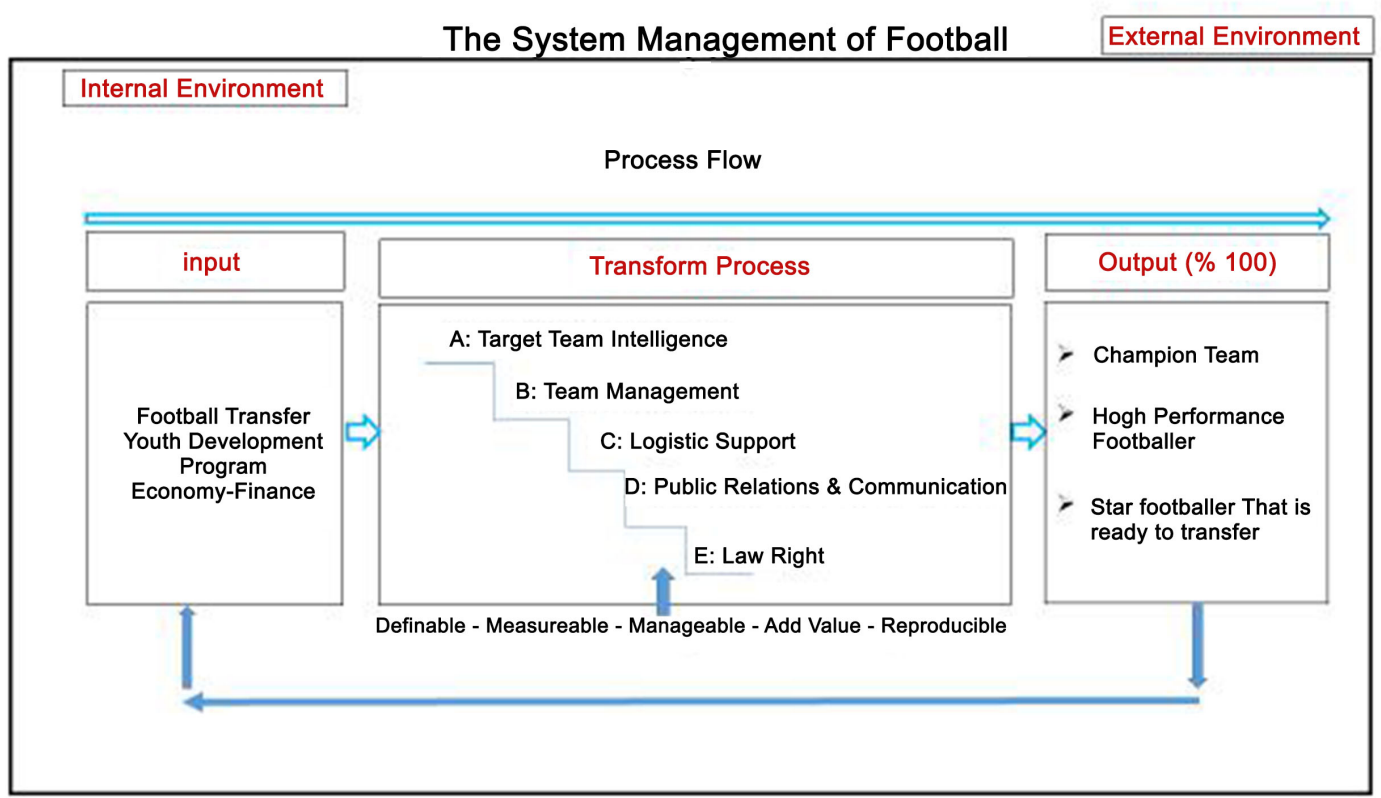

Figure 2. Process of Football Management

Transfer-Youth Development- Economy-Finance issues are going to form input to manage all the main processes in the light of the corporate governance principles, these inputs in process transformation is going to form desired output in accordance with the law, target team intelligence, success of the professional team, public relations, communication, and logistical support that provided on time.

The flow chart for this process is presented in figure-2.

As a result: The modern management approaches to ensure the continuity of sportive success in sports clubs should be utilized. Within this concept, the contribution of the organizational structure to the continuity of the activities carried out in a model that is appropriate to the process management approach and the system approach will be substantial.

The ability of professional sports clubs to create their own financial strength depends on the effective management of the sub-processes related to the main processes of football. The clubs will become the favorite club of the sponsor market and increase their brand awareness through sustainable sportive success.

Sports organizations need to evolve towards a structure that can make the right decisions and predict the future with the experience and knowledge accumulated by updating and creating themselves according to the daily needs.

By the main processes of Football Management, all the units that covering football will be transformed into a structure functioning in the horizontal system, which will make it possible to make the right decisions with the information pool formed by this structure, to be able to prepare itself for technology and environmental changes and to standardize goods and services by means of horizontal and vertical communication facilities to reach the structure that can solve the internal problems and problems related to the process management.

\section{REFERENCES}

[1] (www.uefa.com).

[2] M. Atak. Örgüt yapılarının Evrimi ve Bilgi çağı örgütlerinde Organizasyon Tasarımı, Bilgi çağında yönetim, Paradigma Akademi, İzmir, 2013.

[3] C. Cetin, B. Akın, ve V. Erol. Toplam Kalite Yönetimi ve Güvence Sistemleri (ISO9000: 2000 Revizyonu), Beta Yayıncılik, İstanbul, 2001.

[4] P.Robbins, Stephen ve Judge, A. Timoty. Organizational Behavior, çeviri editörü: İnci Erdem, 14. Baskıdan Çeviri, 2012, Maasie, 1987, Bransel, 1993.

[5] Ö. Doğan. Süreç Tasarımı ve Süreçlerle Yönetim, Paradigma Akademi, İzmir, 2013.

[6] D. M. Ewalt. Prescription for Critical Processes, Information week, Issue: 8, 2002.

[7] Ö. Yavaș. Sporun Ekonomi içindeki yeri ve Spor Pazarlama, Yüksek Lisan Tezi, Edirne Trakya Üniversitesi, 2005.

[8] (www.fcbarcelona.com).

[9] S, Samur. Kurumsal Futbol Yönetimi, Gazi Kitabevi, Ankara, 2013.

[10] J.Stoner. Management, Printice-Hall, New Jersey, 1992.

[11] W.R. Plunkett, R.F, Attner, Introduction to Management PWS-Kent Publishing Company, Thomson/South-Western, 1992.

[12] A.Yıldırım, ve H. Şimşek. Sosyal bilimlerde Nitel Araștırma Yöntemleri, Ankara: Seçkin Yayınları, 2005. 
[13] (www.fcbarcelona.com).

[14] (www.fcbayern.com).

[15] (www.london.edu).

[16] (www.cmoe.com).

[17] (www.telegraph.co.uk.).

[18] (www.hbr.org).

[19] A. Donellon. Takım Dili, Sistem Yayıncılık, İstanbul, s.20, 1998.

[20] M. Toktamışoğlu,' Kot Pantolonlu Yönetici, MediaCat Yayınları, s. 195, Ankara, 2001.

[21] (http://tr.matchstudy.com).

[22] (www.uefa.com).

[23] R. Prindle. A Public Relations Role in Brand Massaging, International Journal of Business and Social Science 2 (18), 32-36, 2011

[24] İ. Aleshina. Public Relations for Managers and Marketers, Gnome Press Publisher, Moscow, 1997

[25] B. F. Peltekoğlu. Halkla İlişkiler Nedir, Beta Yayınları, İstanbul, 2001
[26] C. Berkowitz, K. Hartley, A. Rudelius. Integrated marketing communications and direct marketing, (4th ed) Marketing, Canada: McGraw-Hill Ryerson.; 481-505, 2000.

[27] A. Talimciler. Futbol Değil İş, İletişim Dergisi, 2008.

[28] P. Johansson, ve J. Olhager, Industrial Service Profiling: Matching Service Offerings and Processes, International Journal of Production Economics, Vol. 89, No. 3, 309-320, 2004.

[29] J. Marrian. Marketing Characteristics of Industrial Goods and Buyers, A. Wilson (Der.) 1968.

[30] G, Onal. Temel İşletmecilik Bilgisi. s.142, İstanbul, 1995.

[31] F. Ramazanoğlu. Sporda Sosyal Alanlar. s 13,21,58, Ankara, 2014.

[32] İ. Efil. İşletmelerde Yönetim ve Organizasyon, Alfa Yayınc1l1k, 5.Bask1, s.3-16, Bursa, 1998.

[33] S. Samur. Bilgi Çağında Spor Yönetimi, Gazi Kitapevi, Ankara, 2018.

[34] Ö. Doğan. Süreç Tasarımı ve Süreçlerle Yönetim, Paradigma Akademi, İzmir, 2013.

[35] T. Koçal. İşletme Yöneticiliŭi, Beta Yayıncılık, dokuzuncu bask1, İstanbul, 2003. 